moderate certainty evidence, that there were negligible additive effects from masks in the prevention of respiratory infections. The DANMASK-19 trial showed the mask's protective effect to be inconclusive and difference between the 2 groups to not be statistically significant in the community setting. Despite the evidence from previous RCTs on influenza and other respiratory viral infections, there was suspicion from observational studies ${ }^{8}$ that severe acute respiratory syndrome SARS-CoV-2 behaved differently and that droplet transmission could be mitigated by mask use in the presymptomatic phase..$^{5}$ Therefore, the implementation of universal mask use was justified while awaiting the results DANMASK 19. In light of the inconclusive evidence from DANMASK 19 and the previous RCTs, the case for a protective effect from COVID 19 lacks evidence and requires modification from public health officials.

Although this study did not assess source control, the effect of masks is compelling, when restricted to contacts of index cases receiving the intervention within 36 hours of symptom onset. ${ }^{9}$ Hence, mask use among symptomatic individuals and their contacts is evidence based. On the contrary, long-term effects of mask use among healthy individuals is unknown, ${ }^{3}$ and short-term effects include breathing difficulties, self infection through touching eyes due to irritation from exhaled air from masks, and a false sense of security from mask while neglecting social distancing. ${ }^{10}$ The argument for masks having a variolation effect in COVID-19 is compelling, ${ }^{11}$ but it lacks the support of evidence from cohort studies. Hence, with the current data available, the best case for masks appears to be in symptomatic patients and recommended (not mandatory) use in crowded settings. Wisdom to use measured language in what we "mandate" and "recommend" would be advised. We must decide with prudence, as we did with HCQ, what we choose to be "absolutely essential" measures, and we must decide these based upon robust evidence. In the haste of establishing "life saving" measures, we may be instead be losing the public's trust by not having the supportive evidence and unintentionally placing the lives of the community and healthcare workers at risk.

Acknowledgments. The author's affiliation center belongs to the Integrative Biosciences Center, Wayne State University, Detroit, Michigan. The funders had no role in the decision to publish or preparation of the manuscript.
Financial support. No financial support was provided relevant to this article.

Conflicts of interest. The author reports no conflicts of interest relevant to this article.

\section{References}

1. Boulware DR, Pullen MF, Bangdiwala AS, et al. A randomized trial of hydroxychloroquine as postexposure prophylaxis for COVID-19. $N$ Engl J Med 2020;383:517-525.

2. RECOVERY Collaborative Group, Horby P, Mafham M, Linsell L, Bell JL. Effect of hydroxychloroquine in hospitalized patients with COVID-19. N Engl J Med 2020;383:2030-2040.

3. Javid B, Weekes MP, Matheson NJ. COVID-19: should the public wear face masks? BMJ 2020;369:m1442.

4. Bundgaard H, Bundgaard JS, Raaschou-Pedersen DET, et al. Face masks for the prevention of COVID-19-rationale and design of the randomised controlled trial DANMASK-19. Dan Med J 2020;67:A05200363.

5. Advice on the use of masks in the context of COVID-19: interim guidance. World Health Organization website. https:/www.who.int/publications/i/ item/advice-on-the-use-of-masks-in-the-community-during-home-careand-in-healthcare-settings-in-the-context-of-the-novel-coronavirus-(2019ncov)-outbreak. Published June 5, 2020. Accessed January 26, 2021.

6. Bundgaard H, Bundgaard JS, Raaschou-Pedersen DET, et al. Effectiveness of adding a mask recommendation to other public health measures to prevent SARS-CoV-2 infection in Danish mask wearers: a randomized controlled trial. Ann Intern Med 2020:M20-6817.

7. Chou R, Dana T, Jungbauer R, et al. Masks for prevention of respiratory virus infections, including SARS-CoV-2, in health care and community settings: a living rapid review. Ann Intern Med 2020;173: 542-555.

8. Chu DK, Akl EA, Duda S, et al. Physical distancing, face masks, and eye protection to prevent person-to-person transmission of SARS-CoV-2 and COVID-19: a systematic review and meta-analysis. Lancet 2020;395: 1973-1987.

9. Cowling BJ, Chan KH, Fang VJ, et al. Facemasks and hand hygiene to prevent influenza transmission in households: a cluster randomized trial. Ann Intern Med 2009;151:437-446.

10. Lazzarino AI, Steptoe A, Hamer M, et al. COVID-19: important potential side effects of wearing face masks that we should bear in mind. BMJ 2020; 369:m2003.

11. Gandhi M, Rutherford GW. Facial masking for COVID-19-potential for "variolation" as we await a vaccine. N Engl J Med 2020;383(18):e101.

\title{
Death, masked angels: Die to save someone
}

\author{
Mohammadreza Firouzkouhi PhD (1) and Abdolghani Abdollahimohammad PhD (1) \\ Departments of Medical Surgical, Faculty of Nursing and Midwifery, Zabol University of Medical Sciences, Zabol, Iran
}

"As soon as someone is born, they say, 'He will not be saved from death. For all beings in this world, there is no salvation from death.' " Augustin, 2002

To the Editor - Death usually occurs in old age or after a severe illness, but there is no guarantee regarding when it happens. Death is part of the process of human life. But some human beings

Author for correspondence: Abdolghani Abdollahimohammad, E-mail: abdalqani@ gmail.com

Cite this article: Firouzkouhi M and Abdollahimohammad A. (2022). Death, masked angels: Die to save someone. Infection Control \& Hospital Epidemiology, 43: 549-550, https://doi.org/10.1017/ice.2021.27 consciously risk death to save others regardless of their age and family circumstances, for example, the nurses at the frontline of caring for patients in normal and abnormal situations such as war, epidemics, and crises. In the only pandemic of the 21 st century, nurses are heralded as heroes on the front pages of websites and other media with the phrases such as "battling on the frontline" and "dying in service." Broadcasted images show nurses involved in the coronavirus disease 2019 (COVID-19) pandemic with protective clothing and tired faces behind ever-present masks. The COVID-19 pandemic has meshed politics, economics, health policy, public health, and nurses around the world. The 
importance of nursing has peaked to a point at which all people now praise nurses. Many governments have named a square, street, or a calendar day for nurses in appreciation of their heroic service in battling the COVID-19 pandemic. With the pandemic conditions of 2020, the World Health Organization named 2020 "The Year of Nurse and Midwife."1

Expectations of nurses vary according to their working conditions. Nurses in wars-from frontline combat rescuer and enemy fire service to specialized military and civilian hospitals-are often the only hope for injured soldiers. In the first moments of a crisis, nurses are the first forces on the scene to help the injured and to provide medical care. In the face of diseases such as COVID-19, emergency centers are at the frontline of providing healthcare services. The stories of self-sacrifice and courage published every day by and about nurses on digital media reveal that the soldiers of this war often battle this enemy with the least facilities and the greatest self-sacrifice. Nurses touch and may hug patients to show their sympathy and hope for them. Undoubtedly, the deaths of these medical heroes will never be forgotten.

History has recorded the sacrifice and deaths of nurses in various incidents. ${ }^{2}$ In the American Civil War in the 1860 s, thousands of nurses trained to care for soldiers and lost their lives for threatening to care for soldiers on both sides of the conflict. The 1878 yellow fever epidemic caused 18,000 patients died, and many nurses who provided healthcare services also died. Many nurses lost their lives in the 1918 flu pandemic along with 50 million victims worldwide, which may be comparable to what we are experiencing with COVID-19 today. Nurses have made the ultimate sacrifice caring for millions of patients in other epidemics including polio (1916-1954), the global influenza epidemic (1957-1958), swine flu (2009-2010), Ebola (2014-2016), and zika (2015-2020).

By January 12, 2021, COVID infected $\sim 91,319,487$ and has killed $\sim 1,952,976$, which includes nurses. ${ }^{3,4}$ The International Council of Nurses (ICN) analysis, based on data from our National Nursing Associations, official figures and media reports from a limited number of countries indicates that $>230,000$ nurses have had COVID-19 and >1,500 have died. ${ }^{5}$

Nurses have high intelligence (IQ) and emotional intelligence (EQ), and they sacrifice themselves to save their clients' lives. They also spend a lot of money to be trained and educated.
Nurses are real soldiers of the health who fight invisible enemies in the world. Nurses are at risk for COVID-19, and many are dying in this battle. The increased mortality rate among nurses could be due to the unknown nature of COVID-19, the enormous number of patients hospitalized with COVID-19, direct contact with patient secretions, lack of protective equipment, lack of nursing staff, and long working hours. ${ }^{6}$ Managers should pay more attention to these issues because replacing a nurse is difficult. The nursing profession is a science and an art, and wars and epidemics are increasing the value of nurses and contributing to more positive attitudes toward the nursing profession. The COVID-19 crisis will end one day. Although nurses do not consider themselves heroes and heroines, they deserve respect and honor for their valuable services. Society should always remember the bravery of nurses in fighting COVID-19.

\section{Acknowledgments.}

Financial support. No financial support was provided relevant to this article.

Conflicts of interest. All authors report no conflicts of interest relevant to this article.

\section{References}

1. Bennett CL, James AH, Kelly D. Beyond tropes: towards a new image of nursing in the wake of COVID-19. J Clin Nurs 2020;29:2753-2755.

2. Ebeling MF. Care work on the front lines. Curr Hist 2020;119:326-328.

3. Salter S. From polio to influenza to COVID-19, nation's history offers lessons in perseverance. Clarion Ledger website. https://www.clarionledger.com/ story/opinion/columnists/2020/03/25/polio-covid-19-lessons-column-sidsalter/5049742002/. Accessed May 18, 2020.

4. COVID-19 coronavirus pandemic. World meter website. https://www. worldometers.info/coronavirus/?utm_campaign=homeAdvegas1. Accessed January 12, 2021.

5. Karabulut N, Gürçayır D, Yaman Aktaş Y, et al. The effect of perceived stress on anxiety and sleep quality among healthcare professionals in intensive care units during the coronavirus pandemic. Psychol Health Med 2020. doi: 10. 1080/13548506.2020.1856897.

6. Wang J, Zhou M, Liu F. Reasons for healthcare workers becoming infected with novel coronavirus disease 2019 (COVID-19) in China. J Hosp infect 2020;105:100-101.

\title{
Coronavirus disease 2019 (COVID-19) Brazil Task Force: How to navigate troubled waters
}

\author{
Marcelo Carneiro MD, MSc ${ }^{1}$ (1), Viviane Maria de Carvalho Hessel Dias $\mathrm{PhD}^{1}$, Magda Machado de Miranda Costa RN, MSc ${ }^{2}$, \\ Débora Otero Britto Passos Pinheiro MD¹, Cláudia Fernanda de Lacerda Vidal MD, PhD ${ }^{1}$, Olívia Cristina Palmeira da \\ Silva Rodrigues RN, MSc ${ }^{1}$, Mirian de Freitas Dal Ben Corradi MD ${ }^{1}$, Heiko Thereza Santana RN, MSc ${ }^{2}$, Maria Dolores Santos \\ da Purificação Nogueira BN, MSc², Mara Rúbia Santos Gonçalves PharmD ${ }^{1}$ and Maria Clara Padoveze RN, PhD ${ }^{1}$ \\ ${ }^{1}$ Brazilian Association of Hospital Infection Control and Epidemiology (ABIH), Curitiba, Brazil and ${ }^{2}$ General Management of Technology in Health Services \\ (GGTES), Brazilian Health Regulatory Agency (ANVISA), Brasilia, Brazil
}

\footnotetext{
Author for correspondence: Marcelo Carneiro, E-mail: marceloc@unisc.br

Cite this article: Carneiro M, et al. (2022). Coronavirus disease 2019 (COVID-19)

Brazil Task Force: How to navigate troubled waters. Infection Control \& Hospital

Epidemiology, 43: 550-551, https://doi.org/10.1017/ice.2021.41
}

(c) The Author(s), 2021. Published by Cambridge University Press on behalf of The Society for Healthcare Epidemiology of America. This is an Open Access article, distributed under the terms of the Creative Commons Attribution licence (http://creativecommons.org/licenses/by/4.0/), which permits unrestricted re-use, distribution, and reproduction in any medium, provided the original work is properly cited. 